\title{
The case of historical breeding of Black-Bellied Plover (Pluvialis squatarola) in Central Europe
}

Jiří J. Hudeček

\begin{abstract}
The case of historical breeding of Black-Bellied Plover (Pluvialis squatarola) in Central Europe. - Acta Mus. Siles. Sci. Natur., 66: 231-235, 2017.

Abstract: Black-Bellied Plover (Pluvialis squatarola), is a species breeding in the arctic tundra; in Europe only in Siberian peninsulas on the Russian territory. There is not enough evidence about its historical breeding in Central Europe. Jan Pícha discovered the breeding of Black-Bellied Plover somewhere in Budějovice basin in south Bohemia, possible in the years 1906-1926, possible on the ponds Dvořiště or Volešek. He wrote about in to M. Záleský (visited) and J. Jirsík (in correspondence), and this report has been totally forgotten. Quite approved is Pícha's record of Spotted Redshank's (Tringa erythropus) breeding; Pícha's personality and reliability ensure the correctness of his report. Mating behaviour of Black-Bellied Plover, recorded in South Bohemia also in 1993.
\end{abstract}

Key words: Black-Bellied Plover, Pluvialis squatarola, historical breeding, Central Europe, Budějovice basin, southern Bohemia, Czech Republic, Jan Pícha

\section{Introduction}

Black-bellied Plover, Pluvialis squatarola (Linnaeus, 1758) is a species found in the arctic tundra but also widespread on the shore of the North Arctic Ocean, in Alaska, Canada, and Russia (Messange \& Taylor 2005; O’Brien et al. 2006; Thompson \& Byrkjedal 2011). In Europe it breeding solely on the islands Vaygach and Kolgujev, no in Northern Europe (IsoIvari 1976); on the border of Eurasia, in the west of White Sea, in Russian peninsulas Yamal, Gydan, and Taymyr. Partly it spends winter on the shores of western Africa up to the Gulf of Guinea, but also along Greece, in the eastern Mediterranean, in eastern and southern Africa, in south-eastern India, Malaysia, Australia, and in South America (Anonymus s. d., a,b; Glutz von Blotzheim et al. 1975; Serra et al. 2001; BirdLife International 2016). In Central Europe it is quite plentiful during the spring and autumn migration period, but it is very rare on the northern shore in winter and summer; there is no evidence about its breeding (Glutz von Blotzheim et al. 1975; Hudec \& Št'astný 2005). It spent summers here but did not nest: possible breeding in Germany in Thuringia in 18th century (Borkhausen 1797), according to von Homeyer (1872) and Schmiedeknecht (1906) a individual pairs might have breeding in Germany. More concrete in Lower Saxony, in the former principality Oldenburg (coordinate: 53 ${ }^{\circ} 8^{\prime} 38^{\prime \prime N}, 8^{\circ} 12^{\prime} 50^{\prime \prime} \mathrm{E}$ ) individual pairs were on June 12, 1854 (von Negelein 1853; Wiepken 1854); along Borggreve (1869: 109) but highly improbable. Definite proof about breeding be missing.

\section{Breeding of Black-Bellied Plover in southern Bohemia}

Black-Bellied Plover migrated through southern Bohemia already in the 19th century, which is documented (von Dalla-Torre \& von Tschusi zu Schmidhoffen 1890; Michel 1892; von Schaeck 1892; Bat'a 1933; Hora 1983; Mlíkovský 2004; Čeněk 2006; Pakandl 2014; Kloubec et al. 2015, Mikeš in litt.). But forgotten is the case of its breeding. Záleský (1927) visit of Pícha's collection in 1924, and write at Black-Bellied Plover: "more specimen, one shot to nest !".

Jan Pícha sent a report in correspondence to Josef Jirsík about breeding (not about perhaps or probably) but without any further information or date in a letter from 1926: "I have a lot of things to say, mainly concerning breeding in our area (I'1l name only Totanus fuscus, Squata- 
rola helvetica, Rose-coloured Starling, etc.)" (Jirsík 1955: 95). 1/ Squatarola helvetica is identical with Pluvialis squatarola (Trouessart 1912: 371). In J. Pícha's collection there were two adult specimen and a one juvenile from the ponds Volešek and Dvořisko (Sýkora \& Mayer 1931); according to Bat'a (1933), another one juvenile from this area also from 1916. In the Museum of South Bohemia in České Budějovice there are theses specimen under inventory numbers ZV 148, ZV 149, and ZV 150, without record's data (Fig. 1, 2). Concerning the last two specimen, they were juvenile or birds in the first year of their lives, after partial moulting (Mikeš in litt.). Pícha gave one specimen to the National Museum in Prague in 1906 (Mlíkovský 2004); that all - everything also as physical testimony Pícha's knowledge of this species. Preserved evidence witnesses to the fact that Pícha recognized the Black-Bellied Plover very well. Although the data are not complete, it is possible to think that the Black-Bellied Plover breeding in the Budějovice basin, possible on the pond Dvořiště (coordinate: 49 $3^{\prime} 54^{\prime \prime} \mathrm{N}, 14^{\circ}$ $39^{\prime} 47^{\prime \prime} \mathrm{E}$; area $337 \mathrm{ha}$ ) in the north-west from Třeboň, or pond Volešek (coordinate: $49^{\circ} 4^{\prime}$ 5"N,14¹8'16"E; area 134,4 ha) near Plástovice and in the vicinity of Sedlec near České Budějovice, where Pícha's collection is located between the years 1906-1926. In 1912 Pícha was supposed to have "located a male of the Spotted Redshank, Tringa erythropus (Pallas, 1764), which has led the juvenile" on the pond Velký Hájský in Dubné (coordinate: 48 58'35"N,14²1'37"E) in southern Bohemia; publication priority belong of Jirsík (1935: 497; 1955: 95; Hudeček 2017), not Mlíkovský (2004). This record is quite accepted as the only evidence from the whole Central Europe (Pakandl 2013; Kloubec et al. 2015). Considerate Pícha, authority on waders (Cerha \& Pícha 1931), might have let the Black-Bellied Plover to lead out the juvenile and only then he shot it to death (see of Spotted Redshank, Mlíkovský 2004). The described case of forgotten breeding is backed up by observation of a pair of BlackBellied Plover during mating behaviour and mating on the pond Koclírov (coordinate: $49^{\circ} 4^{\prime} 9^{\prime \prime} \mathrm{N}, 14^{\circ} 41^{\prime} 37^{\prime \prime} \mathrm{E}$, area $192 \mathrm{ha}$ ), to the southwest of Lomnice nad Lužnice. This happened between June 7 and 11, 1993 (Pakandl 2014; Kloubec et al. 2015). Other May, Juny and July observations of individuals were made in southern Bohemia (summary of Hora 1983; Pakandl 2014; Kloubec et al. 2015) and in other places in the Czech Republic during the breeding period: in western Bohemia in 2015 (Anonymus 2015), eastern Bohemia in 1994 (Kadava et al. 2011), southern Moravia in 2007 (Macháček 2012; Sychra et al. s. d.) and central Moravia (Polčák in Šŕrek 2002). According to Pakandl (2014), the spring migration finished in the Czech Republic at the beginning of June and Black-Bellied Plovers stay here during July only very rarely.

\section{Jan Pícha (1872-1930)}

An ophthalmologist, amateur ornithologist and taxidermist, beside Karel Bartuška, the first ornithologist in České Budějovice from the turn of the 19th and 20th centuries until 1930s (Hudec 1999; Kloubec et al. 2015). He was considered to be an expert in natural sciences and an absolutely reliable ornithologist (Záleský 1927; 1930; Jirsík 1955; Mlíkovský 2004). Pícha probably observed of the European Mink, Mustela lutreola (Linnaeus, 1761), on ponds in enviroment of the České Budějovice (Záleský 1930). He made is observation in the environments of České Budějovice unfortunately he did not write down his experience. Nevertheless, he was quoted by important personalities of Czech ornithology and zoology as Karel Kněžourek, Václav Vávra, Jiří Janda, Josef Jirsík, and mostly Miloš Záleský (Kněžourek 1912; Janda 1926; Jirsík 1935; 1955; Záleský 1927). He bequeathed his bird collection to the City Museum in České Budějovice (today's Museum of South Bohemia), and gifts to National Museum in Prague, but without any accompanying written documentation (Cerha \& Pícha 1931; Mlíkovský 2004). The collection counted 233 birds and 110 species (Bat'a 1933; Sýkora \& Mayer 1931; Mikeš s. d.). Some date can be found in literature. 

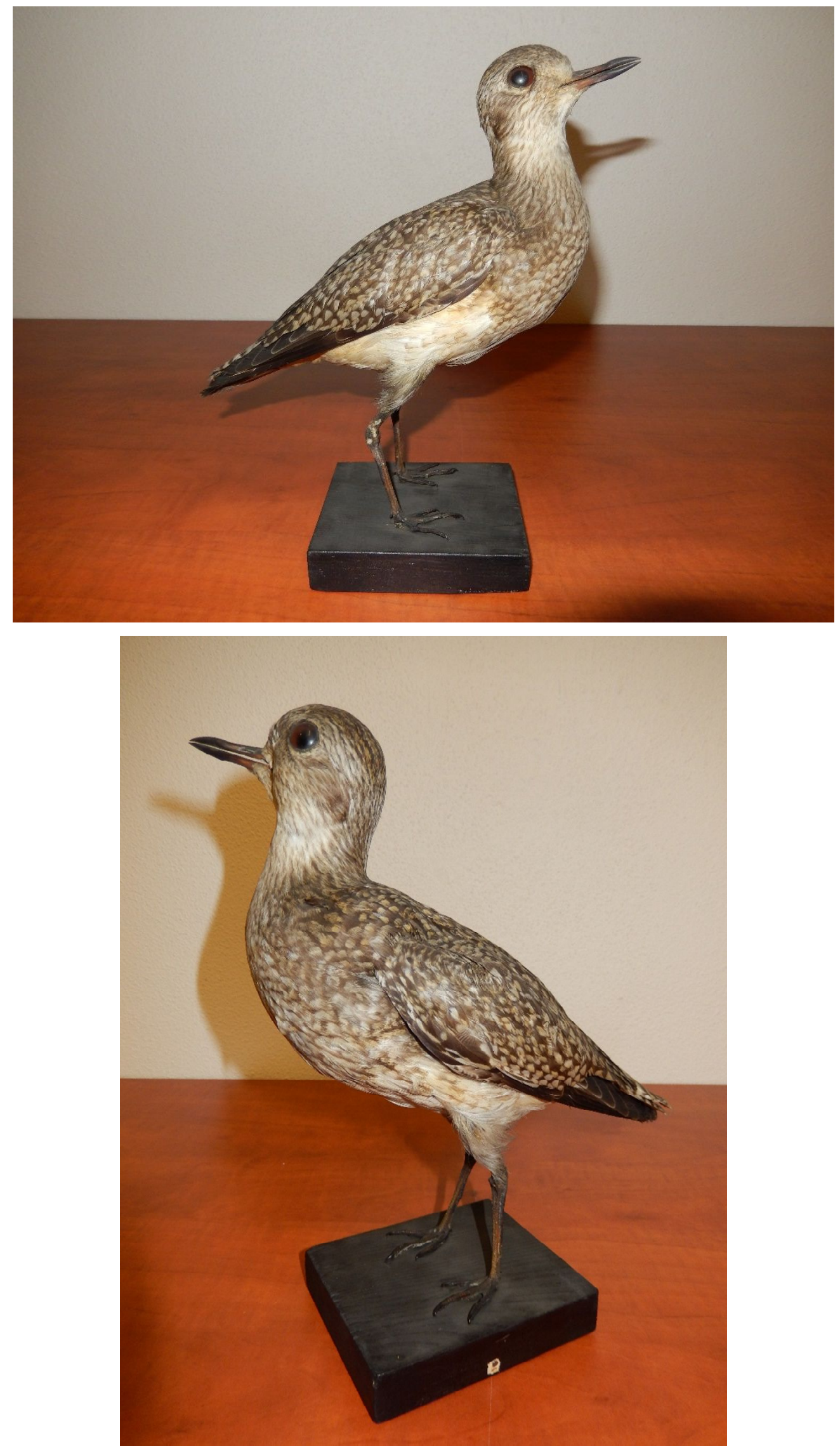

Fig 1-2: Black-Bellied Plover (Pluvialis squatarola): collection of Jan Pícha, without locate and data, probably Budějovice basin (inventory number ZV 150, Museum of South Bohemia in České Budějovice). Photo Václav Mikeš. 


\section{Summary}

This article describes the case of breeding of the Black-Bellied Plover, for sure in southern Bohemia somewhere in the Budějovice basin, possible between 1906 and 1926 (Záleský 1927; Jirsík 1955).This case was mentioned by J. Pícha, a reliable personality and bird expert, in his correspondence with J. Jirsík, and personal contact with M. Záleský. Pícha might not have led any written records but in his collection he had documentary specimen, which shows that he recognized this species very well. This record has been totally forgotten although it presents the only direct statement about the species breeding in Central Europe.

Acknowledgement: For help I thank very much to Marie Indráková (Klimkovice), Anna Kuzníková (Ostrava), and Václav Mikeš (Museum of South Bohemia in České Budějovice).

\section{Notes}

Ad 1: Literal text of Záleský (1927) in Czech: "Kulíka bledého (více exem., jeden střelen na hnízdě !)".

Ad 2: Literal text of Jirsík (1955: 95). "I have many thing's, mainly recorded case's of breeding at our area (at random name only Totanus fuscus, Squatarola helvetica, Rose-coloured Starling etc.). In Czech: "Přímo o hnízdění bohužel bez bližších údajů, napsal autorovi (= J. Jirsíkovi) v dopisu bez data r. 1926, absolutně spolehlivý budějovický ornitolog Dr. Jan Pícha (zemřel r. 1930). Cituji doslova: "...mám mnoho věcí, hlavně zjištěné př́ípady hnízdění u nás ptáků (namátkou jmenuji jen Totanus fuscus, Squatarola helvetica, růžového špačka, atd.)"

\section{References}

Anonymus (2015): Zajímavá ornitologická pozorování v Plzeňském kraji v roce 2015. Available from: http://www.ornitologie-hok.cz/akce/2015/635-zajimava-ornitologicka-pozorovani-v-plzenskem-kraji

- (s. d., a): Grey Plover (Pluvialis squatarola). European birds: online guide. Available from: www.avibirds. $\mathrm{com} / \mathrm{html} /$ Grey-Plover.html

- (s. d., b): Pluvialis squatarola - Grey Plover. Available from: www.birdlife.org/datazone/unserfiles/file/species/ BirdInEuropeII/BiE2004sp3114.pdf

Bat'a L. (1933): Dosavadní výsledky zoologického výzkumu jižních Čech. Sv. 3. Vlastivěd. Společ. Jihočeská, České Budějovice.

Bird Life International (2016): Pluvialis squatarola. The IUCN Red List of Threatened Species. 2016:e.T22693749A86546031: Downloaded on 16 March 2017.

Borggreve B. (1869): Die Vogel-Fauna von Norddeutschland. Julius Springer, Berlin.

Borkhausen M.B. (1797): Deutsche Fauna, oder Kurzgefasste Naturgeschichte der Thiere Deutschlands. I. Theil. Säugethier und Vögel. Varrentrapp und Wenner, Frankfurt am Main.

Cerha P. \& Pícha J. (1931): Za jespáky bojovnými (Machetes pugnax). - Stráž Mysl. 9(14): 238-239.

Čeněk M. (2006): Birds in the collections of the National Agriculture Museum in the hunting lodge Ohrada in Hluboká nad Vltavou. - Zprávy MOS 64: 81-109.

Dalla-Torre K. von \& Tschusi zu Schmidhoffen V. von (1890): VI. Jahresbericht (1887) des Comité 's für ornithologischen Beobachtung-Stationen in Oesterreich-Ungarn. - Ornis 6: 33-154.

Glutz von Blotzheim U.N., Bauer K.M. \& Bezzel E. (1975): Handbuch der Vögel Mitteleuropas. Band 6: Charadriiformes (1. Theil). Akad. Verlagsgesellschaft, Wiesbaden.

Homeyer E.F. von (1872): Bemerkungen über einige Vögel Norddeutschlands, mit besonderer Rücksicht auf die Vögel Pommerns. - J. Orn. 20(119): 332-340.

Hora J. (1983): Der Durchzug des Kibitzregenpfeifers, Pluvialis squatarola (Linnaeus, 1758) in Südböhmen. Sbor. Jihočes. Mus., České Budějovice, Př́rir. vědy 22(suppl. 2): 54-65.

Hudec K. (1999): Ornitologové České republiky. Muzeum Komenského, Asociace českých a moravskoslez. muzeí, Mor. ornitol. stanice, Přerov.

Hudec K. \& Št'astný K. [eds] (2005): Fauna ČR, sv. 29/1. Ptáci-Aves, Díl II/1 (2., přeprac. a doplněné vyd.). Academia, Praha.

Hudeček J.J. (2017): New Books. - Kloubec B., Hora J. \& Št’astný K. [eds] (2015): Ptáci jižních Čech. Acta Mus. Siles., Sci. Natur. 66: 181-184.

Is o-Iivari L. (1976): Check-list of the birds of northern Europe. - Ornis Fenn. 53: 57-69. 
Jirsík J. (1935): Jak žijí zviŕata: Př́rodopis živočišstva. Hynek Buchsbaum, Moravská Ostrava-Př́ivoz.

- (1955): Naši pěvci. Část I. NČSAV, Praha.

Kadava L., Holub A., Poříz J., Bartoníček J. \& Zajíc J. (2011): Birds of Nový Bydžov and Chlumec nad Cidlinou regions. - Panurus 20: 105-182.

Kloubec B., Hora J. \& Št’astný K. [eds] (2015): Ptáci jižních Čech. Nakl. Jihočeský Kraj, České Budějovice.

Kněžourek K. (1912): Velký př́rodopis ptáků se zretetelem ku ptactvu zemí českých a rakouských. Díl II. Nakl. I.L. Kober, Praha.

Macháček J. (2012): Influence of the draining of Nesyt Lake in 2007 on the spring birds migration: 4-12. Available from: www.rnm.cz/region/2012/03_machacek.pdf

Message S. \& Taylor D. (2005): Waders of Europe, Asia \& North America. Christopher Helm, London.

Michel J. (1892): Eine ornithologische Reiseerinnerungen. - Mitt. Ornitol. Ver. Wien 16(14): 163-164.

Mikeš V. (s. d.): Historie sbírek do vzniku profesionálního pracoviště. Zoologická podsbírka. Available from: http://www.muzeum.cz/jihoceske-muzeum/sl

- (in litt.): Sdělení Jiřímu J. Hudečkovi ze dne 13.1.2017.

Mlíkovský J. (2004): Spotted Redshank (Tringa erythropus): a historical breeding record for the Czech Republic. - Sylvia 40: 131-134.

Negelein C.W. von (1853): Verzeichniss der im Herzogthum Oldenburg vorkommenden, hier brütenden und seltener Vögel. - Naumannia 3: 63-64.

O'Brien M., Crossley R. \& Karlson K. (2006): The Shorebird Guide. Haughton Mifflin Company, Boston, New York.

Pakandl M. (2013): Průtah vodouše tmavého (Tringa erythropus) na území České republiky. - Vanellus 8: 3032.

- (2014): Průtah kulíka bledého (Pluvialis squatarola) na území ČR. - Vanellus 9: 39-41.

Serra L., Whitelaw D.A., Tree A.J \& Underhill L.G. (2001): Biometrics, possible breeding origins and migration routes of South African Grey Plovers, Pluvialis squatarola. - Ostrich 72(3-4): 140-144.

Sychra J., Danihelka J., Roleček J., Horal D., Přikryl I., Herolt P., Horsák M., Chytil J., Kubíček F., Květ J. \& Macháček P. (s. d.): Letnění rybníka Nesyt v roce 2007. Available from: www.sci.muni.cz/ danihel/Letneny_Nesyt.pdf

Schaeck F. von (1892): Die ornithologische Sammlung im fürstliche Schwarzenberg 'schen Jagdschlosse "Ohrad" bei Frauenberg in Böhmen. - O. Jb. 2: 69-75.

Schmiedeknecht O. (1906): Die Wirbelthiere Europas mit Berücksichtigung der Faunen von Vorderasien und Nordafrika. O. Fischer, Jena.

Sýkora L. \& Mayer K. (1931): Sbírka ptáků MUDra Jana Píchy. - Jihočes. Přehled 2: 13-16.

Š́r ek J. (2002): Ornitologická pozorování. - Ptáci kolem nás (Mor. Ornitolog) (2): 28-31.

Thompson D. \& Byrkjedal I. (2011): Tundra Plovers: The Eurasian, Pacific and American Golden Plovers and Grey Plovers. T \& AD Poyser Ltd., London.

Trouessart E.-L. (1912): Catalogue des Oiseaux d'Europe pour servir de comple'ment et de supple'ment a e'Ornithologie Europe'ene. Paul Klincksieck, Léon Lhomne, Paris.

Wiepken C.F. (1854): Kurzer Bericht über eine ornithologische Excursion am Jahrdebusen, im Juni 1854. Naumannia 4: 352-357.

Záleský M. (1927): Sbírka ptáků dra Píchy v Č. Budějovicích. - Čes. Myslivost 31(5): 91.

- (1930): Jak byl uloven poslední český norek (Lutreola lutreola L.). - Vesmír 9(4): 84.

Author's address: Jiř́ J. Hudeček, Hraniční 151 \& 230, CZ-742 83 Klimkovice, Czech Republic.

E-mail: waldrapp@seznam.cz 